\section{International Journal of Learning and Teaching}

Volume 09, Issue 3, (2017) 364-369

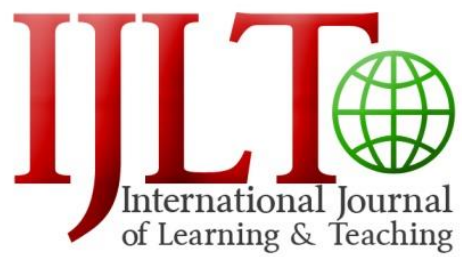

www.ij-lt.eu

\title{
A study of the metacognitive awareness levels of students in Firat University's Faculty of Sports Sciences
}

Evrim Celebi, Department of Midwifery, School of Health Sciences, Firat University, 23119, Elazig,Turkey.

Cemal Gundogdu*, Department of Sport Management, Faculty of Sports Science, Firat University, 23119, Elazig, Turkey.

\section{Suggested Citation}

Gundogdu, C. \& Celebi, E. (2017). A study of the metacognitive awareness levels of students in Firat University's Faculty of Sports Sciences.

(3), 364-369.

Received February 27, 2017; revised May 10, 2017; accepted July 5, 2017.

Selection and peer review under re ponsibility of Prof. Dr. Hafize Keser, Ankara University, Ankara, Turkey. ${ }^{\circledR} 2017$ SciencePark Research, Organization \& Counseling. All rights reserved

\begin{abstract}
This study aims to identify the metacognitive awareness levels of the students studying in the departments of sports management, coaching and physical education. The population of this descriptive study consists of 854 students in the Faculty of Sports Science of Firat University. No sampling was done, and the whole population was included in the study. 684 students answered the questionnaires (participation rate: $80.1 \%$ ). The data of the study were collected with the Metacognitive Awareness Inventory (MAI) and a personal information sheet. As a result of the study, the mean scores of the total MAI of the students of the Physical Education Department (182.6 \pm 27.0$)$, and their mean scores of knowledge of cognition $(59.3 \pm 9.8)$ and regulation of cognition $(123.3 \pm 18.0)$ dimensions were found to be lower than those students' of other departments; and this difference is significant $(p<0.05)$. The total MAI mean scores $(177.7 \pm 30.1)$ of those graduates of a Sports High School, and their mean scores of knowledge of cognition $(58.1 \pm 10.1)$ and regulation of cognition $(119.5 \pm 20.9)$ were found to be significantly lower than those of the graduates of other high schools $(p<0.05)$. Moreover, no significant relationship was found between the MAl and its dimensions and the students' age and gender variables.
\end{abstract}

Keywords: Meta-cognition, metacognitive awareness, student, physical education, sports management.

*ADDRESS FOR CORRESPONDENCE:Cemal Gundogdu, Department of Sport Management, Faculty of Sports Science, Firat University, 23119, Elazig, Turkey. 


\section{Introduction}

One of the main objectives of the contemporary educational approach is to ensure that students are able to control their knowledge and learning processes (Ozsoy \& Gunindi, 2011). Students' active participation in the learning process increases the permanency of their knowledge, their learning levels and make their school years meaningful and productive (Akturk \& Sahin, 2011). One of the key elements of effective education is to teach students how to learn, remember and control the process of doing so (Cakiroglu, 2007). The concept of metacognition is closely related to effective learning and plays a major role in ensuring that students actively participate in learning (Akturk \& Sahin, 2011). The concept of metacognition was added to the literature by Flavell (1979). It involves perceiving, remembering, thinking about and controlling mental processes (Ozsoy, 2008). The underpinning concepts of metacognition are conscious behavior, controlling oneself, organizing and assessing oneself, making a plan, observing the ways to learn and learning to learn (Ozsoy \& Gunindi, 2011). Most researchers claim that students with metacognitive skills are more aware of their strengths and weaknesses and that they spend more effort to improve their own learning skills (Akturk \& Sahin, 2011). In order to teach university students effective learning processes, they should be taught methods to improve their metacognitive skills. If university students have metacognitive awareness, they will take responsibility for their own learning and will be more active and participatory. Thus, it is important that participant students' metacognitive levels are identified since the sports sciences faculty students in the sample of this study will be field experts in the future. This study is significant in the sense that it determines the metacognitive awareness of students in sports sciences, can serve as a resource for future studies and contributes to the relevant literature.

The aim of this study is to determine the metacognitive awareness levels of students in sports sciences and some of the demographic factors that influence this awareness.

\section{Method}

This is a descriptive study. The study population includes 854 students enrolled in Firat University's Sports Sciences Faculty Departments of Sport Management, Coaching and Physical Education Teaching in the 2015 Spring semester. The students attend classes regularly. The authors did not select a sample. All students were included in the sample and the author reached 684 students $(80.1 \%)$.

The data were collected using a personal information form created by the researchers and the Metacognitive Awareness Inventory (MAl). The personal information form consisted of questions about students' age, departments, the high schools they attended, number of siblings, family type and their perception of their economic status. The MAI was created by Schraw and Dennison (1994), and it was translated into Turkish by Akin, Abaci and Cetin (2007). The inventory includes eight subscales in two sub-dimensions, which are are the knowledge of cognition and the regulation of cognition. The knowledge of cognition dimension includes these sub-scales: declarative knowledge, procedural knowledge and conditional knowledge. The regulation of cognition dimension includes these sub-scales: planning, comprehension monitoring, evaluation, debugging strategies and information management. The inventory includes 52 five-point Likert type questions and the possible scores on the scale range from 52 to 260 . Higher scores on the MAl indicate an advanced level of metacognitive awareness. The MAI was administered to the students in the classroom after the necessary explanations, and they were observed while answering the questions. Written consent was obtained from Firat University's Non-Invasive Research Ethics Committee Directorship before the 
survey was conducted.

The data were analyzed by numbers, mean scores, percentages and ANOVA. The study found that the Cronbach's $\alpha$ was 0.94 for the entire MAl, 0.86 for the knowledge of cognition sub-dimension and 0.91 for the regulation of cognition sub-dimension.

\section{Results}

The average age of the participants is $21.8 \pm 2.7$ of them, $42 \%$ are students in the Department of Coaching, 35.4\% in the Department of Sports Management and $22.7 \%$ in the Department of Physical Education Teaching.

Table 1. Distribution of students according to socio-demographic characteristics

\begin{tabular}{|c|c|c|c|}
\hline Characteristics & & $\mathrm{N}$ & $\%$ \\
\hline \multicolumn{4}{|l|}{ Age } \\
\hline 19 years and younger & & 125 & 18.3 \\
\hline 20-23 years old & & 407 & 59.5 \\
\hline 24 years old and over & & 152 & 22.2 \\
\hline \multicolumn{4}{|l|}{ Type of High School Graduated } \\
\hline Normal high school & & 438 & 64.0 \\
\hline Sports high school & & 82 & 12.0 \\
\hline Vocational high school & & 100 & 14.6 \\
\hline $\begin{array}{l}\text { Anatolian, Science, and } \\
\text { Language Intensive high schools }\end{array}$ & Foreign & 64 & 9.4 \\
\hline \multicolumn{4}{|l|}{ Number of siblings } \\
\hline 2 and under & & 257 & 37.6 \\
\hline 3 and over & & 427 & 62.4 \\
\hline \multicolumn{4}{|l|}{ Family type } \\
\hline Nuclear family & & 440 & 64.4 \\
\hline Extended family & & 230 & 33.6 \\
\hline Divorced family & & 14 & 2.0 \\
\hline \multicolumn{4}{|l|}{ Perception of economic status } \\
\hline Low income & & 118 & 17.2 \\
\hline Middle income & & 534 & 78.1 \\
\hline High income & & 32 & 4.7 \\
\hline
\end{tabular}

Of the participants, $64 \%$ attended regular high schools, $62.4 \%$ have three or more siblings, $64.4 \%$ were from nuclear families, and $78.1 \%$ thought they had an average income (Table 1 ).

Table 2. Distribution of Students' Scores on MAI and its Sub-scales

\begin{tabular}{llll}
\hline & & & \\
MAl and Sub-Scales & Mean \pm SD & Min. & Max. \\
\hline Knowledge of cognition & $62.6 \pm 10.3$ & 26 & 85 \\
Declarative knowledge & $26.2 \pm 4.6$ & 11 & 35 \\
Procedural knowledge & $14.1 \pm 2.8$ & 4 & 20 \\
Conditional knowledge & $22.2 \pm 4.1$ & 8 & 30 \\
Regulation of cognition & $127.2 \pm 19.6$ & 57 & 175 \\
Planning & $25.6 \pm 4.5$ & 10 & 35 \\
Monitoring & $29.1 \pm 5.0$ & 13 & 40 \\
Evaluation & $21.9 \pm 3.9$ & 8 & 30 \\
Debugging strategies & $17.6 \pm 3.4$ & 7 & 25 \\
Information management & $32.7 \pm 5.5$ & 12 & 45 \\
MAI Total & $189.8 \pm 29.0$ & 83 & 260 \\
\hline
\end{tabular}

The students' mean score on the knowledge of cognition sub-dimension is $62.6 \pm 10.3$, while their mean score on the regulation of cognition sub-dimension is $127.2 \pm 19.6$, and their total MAl mean 
Celebi, E. \& Gundogdu, C. (2017). A study of the metacognitive awareness levels of students in Firat University's Faculty of Sports Sciences. (3), 364-369

score is $189.8 \pm 29$ (Table 2).

Table 3. Distribution of scores on the knowledge of cognition sub-dimension by department and high school type

\begin{tabular}{|c|c|c|c|}
\hline \multirow{3}{*}{ Variables } & \multicolumn{3}{|l|}{ Knowledge of Cognition } \\
\hline & Declarative knowledge & Procedural knowledge & $\begin{array}{l}\text { Conditional } \\
\text { knowledge }\end{array}$ \\
\hline & Mean $\pm S D$ & Mean \pm SD & Mean \pm SD \\
\hline \multicolumn{4}{|l|}{ Department } \\
\hline $\begin{array}{l}\text { Physical Education and Sports } \\
\text { Teaching }\end{array}$ & $24.3 \pm 5.0 *$ & $13.6 \pm 2.5^{*}$ & $21.3 \pm 3.5^{*}$ \\
\hline Sports Management & $27.0 \pm 4.3$ & $14.1 \pm 2.8$ & $22.5 \pm 4.3$ \\
\hline Coaching & $26.5 \pm 4.4$ & $14.3 \pm 2.8$ & $22.5 \pm 4.2$ \\
\hline $\mathrm{p}$ & 0.000 & 0.020 & 0.008 \\
\hline \multicolumn{4}{|l|}{ Type of High School Graduated } \\
\hline Normal high school & $26.2 \pm 4.6$ & $13.9 \pm 2.9$ & $22.3 \pm 4.1$ \\
\hline Sports high school & $24.1 \pm 4.7^{*}$ & $13.5 \pm 2.5^{*}$ & $20.5 \pm 3.8^{*}$ \\
\hline Vocational high school & $27.1 \pm 4.4$ & $14.7 \pm 2.5$ & $22.9 \pm 4.4$ \\
\hline $\begin{array}{l}\text { Anatolian, Science, and Foreign } \\
\text { Language Intensive high schools }\end{array}$ & $26.9 \pm 4.3$ & $14.9 \pm 2.4$ & $22.8 \pm 4.6$ \\
\hline $\mathrm{p}$ & 0.000 & 0.002 & 0.000 \\
\hline
\end{tabular}

Students in the Department of Physical Education Teaching had lower scores than the other students in declarative knowledge, procedural knowledge and conditional knowledge sub-scales $(p<0,05)$. Students who graduated from sports high schools obtained lower scores than the graduates of other types of high schools on these sub-scales $(p<0,05$; Table 3$)$.

Table 4. Distribution of Mean Scores on the Regulation of Cognition Sub-dimension According to Departments and High Schools

\begin{tabular}{|c|c|c|c|c|c|}
\hline \multirow[b]{2}{*}{ Variables } & \multicolumn{3}{|c|}{ Regulation of Cognition } & \multirow[b]{2}{*}{$\begin{array}{l}\text { Debugging } \\
\text { strategies } \\
\text { Mean } \pm S D \\
\end{array}$} & \multirow[b]{2}{*}{$\begin{array}{l}\text { Information } \\
\text { management } \\
\text { Mean } \pm S D\end{array}$} \\
\hline & $\begin{array}{l}\text { Planning } \\
\text { Mean } \pm S D\end{array}$ & $\begin{array}{l}\text { Monitoring } \\
\text { Mean. } \pm \text { SD }\end{array}$ & $\begin{array}{l}\text { Evaluation } \\
\text { Mean } \pm S D\end{array}$ & & \\
\hline \multicolumn{6}{|l|}{ Department } \\
\hline $\begin{array}{l}\text { Physical Education and } \\
\text { Sports Teaching }\end{array}$ & $24.8 \pm 4.3^{*}$ & $29.2 \pm 4.9$ & $21.6 \pm 3.4$ & $16.8 \pm 2.9 *$ & $31.5 \pm 4.9 *$ \\
\hline Sports Management & $26.0 \pm 4.5$ & $29.4 \pm 4.9$ & $22.1 \pm 3.9$ & $17.7 \pm 3.6$ & $32.8 \pm 5.6$ \\
\hline Coaching & $25.7 \pm 4.6$ & $29.1 \pm 5.0$ & $21.9 \pm 3.9$ & $18.1 \pm 3.4$ & $33.3 \pm 5.7$ \\
\hline $\mathrm{p}$ & 0.042 & 0.131 & 0.432 & 0.001 & 0.008 \\
\hline \multicolumn{6}{|l|}{ Type of High School } \\
\hline \multicolumn{6}{|l|}{ Graduated } \\
\hline Normal high school & $25.6 \pm 4.5$ & $29.0 \pm 5.0$ & $21.8 \pm 3.8$ & $17.6 \pm 3.4$ & $32.7 \pm 5.4$ \\
\hline Sports high school & $23.9 \pm 5.1^{*}$ & $27.7 \pm 5.2^{*}$ & $21.2 \pm 4.0^{*}$ & $16.7 \pm 3.6^{*}$ & $29.9 \pm 5.6^{*}$ \\
\hline Vocational high school & $26.3 \pm 4.4$ & $30.1 \pm 4.9$ & $22.8 \pm 4.4$ & $18.0 \pm 3.2$ & $34.6 \pm 5.0$ \\
\hline Anatolian, Science, and & $26.6 \pm 4.1$ & $30.1 \pm 4.5$ & $22.5 \pm 3.8$ & $18.6 \pm 3.2$ & $33.4 \pm 5.3$ \\
\hline Language & & & & & \\
\hline \multicolumn{6}{|l|}{ Intensive high schools } \\
\hline$p$ & 0.001 & 0.004 & 0.019 & 0.006 & 0.000 \\
\hline
\end{tabular}

The students in the Department of Physical Education Teaching had significantly lower scores than the other students on planning, debugging strategies and information management sub-scales (Table

4). The students who graduated from sports high schools obtained lower scores on the planning, debugging strategies, evaluation, comprehension monitoring and information management subscales than the graduates of other types of high schools $(p<0.05$; Table 4$)$.

This study found that the students' number of siblings, family type and perception of economic status did not significantly influence metacognitive awareness $(p<0.05)$. 


\section{Discussion, Conclusion and Recommendations}

The average age of the participants is $21.8 \pm 2.7$. The average age of the students in the study by Nazik (2014) is $22.6 \pm 2.1$, and it is $23.2 \pm 2.8$ in a study by Kiremitci (2013). Of them, 64\% graduated from regular high schools (Table 1). $39.6 \%$ of participant students graduated from regular high schools in the study by Kiskir (2011). The majority of students (78.1\%) reported that they had low incomes (Table 1). In the study by Akyolcu (2013), 52\% of students said that they had intermediate levels of income.

The students' mean score on MAl is $189.8 \pm 29$ (Table 2). A review of the relevant literature indicates that studies have varying results. For instance; pre-service teachers' total MAI mean score is $177.9 \pm 24.5$ in a study by Kiskir. Aydin and Coskun (2011) did a study of teachers, and their participants' mean score is 192.8 \pm 26.6 , while in the study by Ayazgok and Yalcin (2014), the participants' mean score is $214.0 \pm 16.4$.

The students' mean score on the MAl's knowledge of cognition sub-dimension is $62.6 \pm 10.3$ (Table 2). In a study by Bedel, the mean for this sub-dimension is $64.2 \pm 9$. In a study by Yildirim (2010), the mean for this sub-dimension is $59 \pm 8,95$. In this study, participants' mean score on the regulation of cognition sub-dimension is 127.2 \pm 19.6 . The results of other studies are similar (Bedel, 2012; Yildirim, 2010).

An analysis of students' scores on the MAl by department shows that students in the Department of Physical Education Teaching obtained the lowest scores on the declarative knowledge, procedural knowledge, conditional knowledge, debugging strategies and information management sub-scales which are also significantly lower than the scores of students in other departments (Table 3 ). This difference may be due to the fact that the students in the Departments of Coaching and Sport Management are aware that they will continue their professional lives in a more competitive environment. The results of the study by Kiremitci (2013) are in accordance with these results.

Sport high school-graduates obtained significantly lower MAl total scores and sub-scale mean scores (Table 2 and 3 ) than the graduates of other types of high schools. Possible reasons for their lower scores are their predominant interest in sports. They improve themselves in this field and attribute secondary importance to cognition. According to the results of a study by Cihanoglu (2012), high school type does not influence metacognitive awareness.

There was no significant correlation between students' perceptions of economic status and their metacognitive awareness scores. The results of the study by Akyolcu (2013) support this study's findings. On the other hand, some studies have found a significant correlation between economic status and metacognitive awareness levels (Saban \& Saban, 2008; Nazik, Sonmez \& Gunes, 2014).

This study's results show that:

- The metacognitive awareness levels of the participant students are above intermediate.

- The metacognitive awareness level varies among departments and the mean score of the students in the Department of Physical Education Teaching is significantly lower than that of the other students.

- Metacognitive awareness varied significantly by the type of high school attended, and sport high school graduates obtained the lowest scores.

- Perceived economic status did not influence metacognitive awareness.

These results suggest that educational methods that improve metacognitive awareness should be included in curricula starting in the early stages of education, particularly in sports high schools. The metacognitive dimension should be considered in curricula and by the academicians who organize educational activities at universities to enhance metacognitive awareness.

\section{References}

Akin, A., Abaci, R., \& Cetin, B. (2007). The validity and reliability of the turkish version of the metacognitive awareness inventory. $655-680$

Akturk, A.O., \& Sahin, I. (2011) Metacognition and computer teaching.

Akyolcu, R. (2013). 383-407

(Unpublished Master Thesis), Gazi University Institute of Education 
Sciences Ankara, Turkey.

Ayazgok, B., \& Yalcin N. (2014). The Investigation of the metacognitive awarness and the academic achievement about simple machine in 7 th grade students in primary education. $774-780$.

Aydin, F., \& Coskun, M. (2011). Geography teacher candidates' metacognitive awareness levels: a case study from Turkey. 551-557.

Bedel, E. F. (2012). An examination of locus of control, epistemological beliefs and metacognitive awareness in preservice early childhood teachers.

Cakiroglu, A. (2007). Metacognition. 21-27.

3051-3060

Cihanoglu, M. O. (2012). Metacognitive awareness of teacher candidates.

$4529-4533$

Kiremitci, O. (2013). An Investigation on metacognitive awareness levels of school of physical education and sport students. 29-40.

Kiskir, G. (2011).

Sciences, Erzurum, Turkey.

(Unpublished Master Thesis), Ataturk University Institute of Education

Nazik, F., Sonmez, M., \& Gunes, G. (2014). The investigation of metacognition levels in nursing students to some variables.

$145-150$.

Ozsoy, G. (2008). Metacognition.

713-740.

Ozsoy, G., \& Gunindi, Y. (2011). Prospective preschool teachers' metacognitive awareness 430-440.

Saban, A. I. \& Saban, A. (2008). An investigation of elementary school teaching department students' metacognition awareness and motivation in terms of some socio-demographic variables.

(1), 35-58.

Yildirim, S. (2010)

Social Sciences. Tokat, Turkey.

(Unpublished Master Thesis), Gaziosmanpasa University Institute of 